\title{
Mannose-binding lectin gene polymorphism and the susceptibility of sepsis: A meta-analysis
}

\section{Zhihua Hu ( $\nabla$ h992200@yeah.net)}

The First Affiliated Hospital of Hainan Medical University https://orcid.org/0000-0002-8856-0613

\section{Shaowen Cheng}

Hainan Medical College: Hainan Medical University, Hainan Medical University

Xini Liu

Hainan Medical College: Hainan Medical University, Hainan Medical University

Lina Xian

Hainan Medical College: Hainan Medical University, Hainan Medical University

\section{Xinyuan Liang}

Hainan Medical College: Hainan Medical University, Hainan Medical University

\section{Fanyu Guo}

Hainan Medical College: Hainan Medical University, Hainan Medical University

\section{Yudie Wang}

Hainan Medical University, Hainan Medical University

\section{Mingdong $\mathrm{Hu}$}

Hainan Medical University, Hainan Medical University

Chuanzhu Lv

Hainan Medical University, Hainan Medical University

\section{Huaping Liang}

Hainan Medical University, Hainan Medical University

Jun Song

Hainan Medical University, Hainan Medical University

\section{Original research}

Keywords: sepsis, gene polymorphism, mannose-binding lectin, meta-analysis, susceptibility

Posted Date: May 17th, 2021

DOl: https://doi.org/10.21203/rs.3.rs-446988/v1

License: (1) This work is licensed under a Creative Commons Attribution 4.0 International License. Read Full License 


\section{Abstract}

Objective To assess the association between the Mannose-binding lectin (MBL) gene polymorphism and the susceptibility to sepsis using a meta-analysis.

Methods The publications were searched on PubMed, Embase, and Web of Science databases up to December 1, 2019 for relevant literature.

Results A total of 32 studies ( 21 adult and 11 pediatric studies) were selected for analysis. Overall, in the three models of $M B L+54 A / B$ gene polymorphisms, namely the dominant model $B B+A B$ vs. $A A(p=$ $0.03)$, the recessive model $B B$ vs. $A B+A A(p<0.00001)$, and the allele model $B$ vs. $A(p=0.04), M B L$ $+54 \mathrm{~A} / \mathrm{B}$ was significantly related to the risk of sepsis. In the adult group, the MBL $\mathrm{A} / 0$ gene polymorphism was associated with the risk of sepsis in the dominant model $\mathrm{AO}+00$ vs. AA $(p=0.006)$ as well as in the allele model $O$ vs. $A(p=0.04)$. The $M B L+54 A / B$ gene polymorphism was significantly related to the risk of sepsis in the recessive model and, therefore, may increase the risk of sepsis. In the pediatric group, no polymorphic loci were significantly associated with sepsis in any of the three models. The results of the publication bias test demonstrated no publication bias in an unadjusted estimate of the relationship between MBL $A / 0$ and $-211 Y / X$ gene polymorphism and sepsis.

\section{Introduction}

Sepsis is one of the most common serious complications following trauma, burns, shock, infections, and other clinically critical illnesses in patients and is also a primary cause of death in intensive care unit (ICU) patients [1]. The condition of sepsis is complex and can progress quickly. If not diagnosed and treated in time, it can easily develop into severe sepsis or even septic shock. When more than three organs or systems are involved, the fatality rate is extremely high [2]. Even when using the same intervention method, the clinical outcomes may be quite different among patients with sepsis. Studies have shown that among the high-risk factors of infection and sepsis, genetic factors have twice the pathogenic effect of environmental factors $[3,4]$.

Mannose-binding lectin (MBL) is one of the component glycoproteins of the complement system and is a first-line anti-infective molecule, playing a critical role in the body's natural immunity and prevention of infection. When the body experiences sepsis, MBL can affect the secretion of a series of cytokines, which influences the balance of inflammation in the body and may mediate the progress of sepsis [5]. The serum expression of $\mathrm{MBL}$ is closely related to the gene polymorphism of $\mathrm{MBL}$. MBL gene mutations can also cause a decrease in the level of MBL in the serum, hindering the activation of the complement system and affecting the body's immune response [6.7]. Current research on the MBL gene polymorphism primarily focuses on six polymorphic sites, including three mutation sites in the promoter region $(-550 \mathrm{H} / \mathrm{L}$, $-221 \mathrm{X} / \mathrm{Y}$, and $+4 \mathrm{P} / \mathrm{Q}$ ) and three sites in the exon 1 region. Single-base mutations in codons 52,54 , and 57 in the exon 1 region results in the substitution of cysteine (Cys) for arginine (Arg), aspartic acid (Asp) for glycine (Gly), and glutamic acid (Glu) for glycine (Gly) in the encoded collagen amino acids. The alleles 
corresponding to the mutations at these three sites are named $\mathrm{D}, \mathrm{B}$, and $\mathrm{C}$ and are collectively referred to as $\mathrm{O}$, with the wild type referred to as $\mathrm{A}$ [8]. The above $\mathrm{MBL}$ gene polymorphic site mutations impact the protective effect of MBL on the body and can increase the susceptibility to infectious diseases [9].

Garred et al. [10] used blood samples from 272 patients with systemic inflammatory response syndrome (SIRS) to demonstrate that MBL mutant alleles primarily exist in patients with a high risk of sepsis. Furthermore, patients with low serum MBL levels are more likely to experience sepsis. Another study found that the blood MBL level of neonates and preterm infants with sepsis was significantly lower than that of children without sepsis and that preterm infants with MBL exon 1 allele B were more likely to develop neonatal sepsis and lung infections $[8,9,11]$. Therefore, MBL expression level, activity changes, and genetic polymorphisms have a certain reference value for predicting the illness changes and the prognosis of patients with sepsis and are important candidate genes to study for early warning signs and diagnostic methods for sepsis. Dzwonek et al. [12] performed MBL phenotype and genotype analyses $(A / O, A / A$, and $O / O)$ on 120 newborn samples the third day after birth and suggested that the risk of developing sepsis was not significantly related to the MBL genotype. Hartz et al. [9] recently conducted a large-scale study that collected samples from 6,878 extremely low birth weight infants, then genotyped MBL2 and divided the plasma levels into normal ( $\mathrm{A} / \mathrm{A})$ and low $(\mathrm{A} / \mathrm{O}$ or $\mathrm{O} / \mathrm{O})$, ultimately demonstrating no association between the MBL level based on genotype. However, there seemed to be an association between $\mathrm{O} / \mathrm{O} \mathrm{MBL}$ levels and the risk of gram-negative sepsis in babies born between 32 and 36 weeks gestation.

An increasing number of studies are being reported on the association between the MBL gene polymorphism and the risk of sepsis, but the results obtained for different populations, regions, research design types, and sample sizes have varied greatly, to the point of being contradictory. Therefore, the current study used a comprehensive and systematic literature review to evaluate the published genetic association studies between MBL gene polymorphism and the risk of sepsis using a meta-analysis.

\section{Materials And Methods}

\subsection{Literature search.}

The three major medical literature databases of PubMed, Embase, and Web of Science were selected for the literature search; articles on the association between the MBL gene polymorphism and sepsis published before December 1, 2019 were selected. The search keywords used were "MBL", "mannosebinding lectin", "mannose-binding protein", "sepsis", "severe sepsis", "septic shock" "polymorphism", and "genetic variant or mutation".

Studies that fulfilled the following criteria were selected: (1) The original article on the association between the MBL gene polymorphism and sepsis was published in a peer-reviewed journal; (2) the study design used cross-sectional observation or was a case-control, nested case-control, or cohort study; (3) the language of publication was English; (4) the paper provided statistical data on the association 
between various genotypes of the MBL gene polymorphism and the risk of sepsis, which could be used for the meta-analysis.

\subsection{Literature quality assessment.}

Two investigators independently extracted data and cross-checked one another. After reviewing all the relevant data, Endnote (a document management tool) was used to exclude overlapping documents between the databases. The two researchers then independently reviewed the titles and abstracts of every article, screening out relevant research documents according to unified standards, cross-checking the screening results, then discussing any inconsistencies until they reached a consistent conclusion. In addition, the original articles, reviews, and meta-analysis references that met the inclusion criteria were reviewed and the missing articles were supplemented, and finally, the summary analysis was performed.

\subsection{Statistical analysis.}

All statistical analyses were performed using Review Manager 5.2 (The Cochrane Collaboration, Oxford, UK) and STATA 11.0 (StataCorp LP, College Station, Texas, USA). The included studies were first tested for heterogeneity. $A p>0.1$ was used to indicate that the heterogeneity between the results of each study was not statistically significant, suggesting that the fixed effects model could be used for analysis, otherwise, the random-effects model was used. The heterogeneity analysis was conducted by using Cochran $\mathrm{Q}$ statistics and the $I^{2}$ test to qualitatively and quantitatively evaluate the heterogeneity between the different studies of polymorphic sites of the same gene. The combined effect size, OR value, and its $95 \%$ $\mathrm{Cl}$ were reported and a forest map was then drawn. The funnel plots, Begg's test, and Egger's test were used to assess the possibility of publication bias.

\section{Results}

A total of 1,620 articles were retrieved from the three major databases and 184 articles were selected after duplicate articles were excluded by ENDNOTE. Two researchers browsed the titles and abstracts of the 184 articles that were selected and excluded 123 articles according to the inclusion criteria (among them, 37 review articles, 4 meta-analysis articles, and 82 articles inconsistent with the research content), leaving 61 articles, 31 of which were chosen after reading the full text of the articles with reference to the inclusion and exclusion criteria. Finally, the original articles were read and a meta-analysis was conducted on the literature that met the inclusion criteria, with one missing related article supplemented. For the final analysis, 32 articles were included, 21 of which included adults and 11 of which included

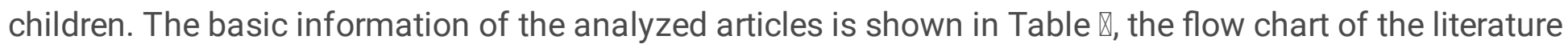

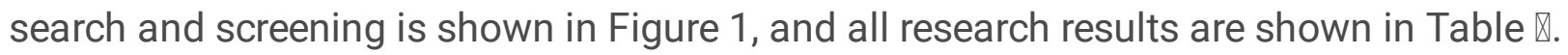

For the overall meta-analysis of $A / O$ polymorphism, in the allele model $O$ vs. $A, O R=1.14,95 \% \mathrm{Cl}: 1.00-$ $1.29, p=0.04 ; I^{2}=43 \%, p=0.03$. There was no significant heterogeneity between studies $\left(I^{2}<50 \%\right)$, so the fixed effects model was used for combined analysis and allele 0 was related to the risk of sepsis, with results suggesting it may increase the risk of sepsis (Figure 2). There was also a significant correlation 
between the $+54 \mathrm{~A} / \mathrm{B}$ polymorphism and the risk of sepsis was demonstrated in the dominant model (OR $=2.01,95 \% \mathrm{Cl}: 1.08-3.75, p=0.03)$, the recessive model $(\mathrm{OR}=6.32,95 \% \mathrm{Cl}: 3.89-10.27, p<0.00001)$, and allelic model ( $\mathrm{OR}=2.09,95 \% \mathrm{Cl}: 1.03-4.24, p=0.04)$ in the overall comparison (Figure 3$)$, while the $-221 \mathrm{Y} / \mathrm{X}$ and $-550 \mathrm{H} / \mathrm{L}$ polymorphisms demonstrated no obvious association with the susceptibility of sepsis in any models.

The results of the meta-analysis in the adult group suggest that the $\mathrm{A} / \mathrm{O}$ gene polymorphisms in the dominant model (OR $=1.37,95 \% \mathrm{Cl}: 1.10-1.72, p=0.006)$ and the allelic model $(\mathrm{OR}=1.19,95 \% \mathrm{Cl}: 1.00$ $1.41, p=0.04$ ) are related to the susceptibility of sepsis (Figure 4$)$. The $+54 \mathrm{~A} / \mathrm{B}$ gene polymorphism was associated with sepsis in the recessive model, demonstrating an increase in the risk of sepsis $(O R=6.32$, $95 \% \mathrm{Cl}: 3.89-10.27, p<0.00001$, Figure 5). No positive association of the $-221 \mathrm{Y} / \mathrm{X}$ polymorphism was demonstrated with the susceptibility of sepsis.

In the pediatric group, there was no positive association of $\mathrm{A} / \mathrm{O}$ polymorphism observed with the risk of sepsis.

The funnel plots, Begg's test, and Egger's test were used to assess the possibility of publication bias. For the total and adult groups, the results demonstrated there was no publication bias in the unadjusted estimate of the association between MBL A/O and the $-211 \mathrm{Y} / \mathrm{X}$ gene polymorphism and sepsis; Egger's test $p=0.270$ and Begg's test $p=0.266$ in the allelic model $O$ vs. A for the total group (Figure 6); Egger's test $p=0.334$ and Begg's test $p=0.767$ in the allelic model $X$ vs. Y for the total group (Figure 7); Egger's test $p=0.117$ and Begg's test $p=0.244$ in the allelic model $O$ vs. A in adults (Figure 8); Egger's test $p=$ 0.137 , Begg's test $p=0.304$ in the allelic model $X$ vs. $Y$ in adults (Figure 9).

\section{Discussion}

In recent years, there has been an increase in both domestic and foreign research on MBL gene polymorphism and sepsis. However, there are certain limitations in this area. For example, the small quantity of samples increases the possibility of false-positives and false-negatives from various geographic regions and ethnicities, while the inconsistencies in the composition of the control population in the study, the various underlying diseases, the inconsistent research methods, and the different levels of MBL concentrations all have a different integration ability for various pathogens, particularly for children of different ages.

The MBL gene has different mutation frequencies in different population types. For example, the mutation frequency of Asp54 in a population from Hong Kong is 0.11 , while it is 0.19 in a population from England, and is very rare among Africans. The mutation frequency of Glu57 in Caucasians is 0.02 and in African Gambians is 0.29 , however, Cys52 has always maintained a low mutation frequency in the study population [44].

Liu. et al. [45] performed genotyping (GG, GA, AA, G, A) on the MBL2 gene rs1800450 polymorphism (codon 54A/B, G230A) in patients with sepsis and found that allele genes can significantly increase the 
risk of sepsis. The GA genotype is closely related to the onset of sepsis, while the AA genotype is not significantly related to the occurrence of sepsis. Furthermore, the frequency of the GA genotype and the $A$ allele based on the MBL2 gene rs 1800450 polymorphism was significantly increased and further ELISA testing demonstrated that the serum MBL level of the sepsis group was significantly lower than that of the control group, as was the MBL level of the rs 1800450 genotype. There was also a significant downward trend, so it is inferred that the rs $1800450 \mathrm{~A}$ allele increases the risk of sepsis by reducing $\mathrm{MBL}$ levels. A 2015 study showed that the B allele of the A/B polymorphism is a risk factor for sepsis in Turks [46]. Huh et al. [47] included a total of 266 sepsis patients and 398 healthy patients and detected three single nucleotide polymorphisms $(54,-550,+4)$ in the MBL2 gene related to sepsis in a Korean population. Seemingly, a single nucleotide polymorphism has nothing to do with the occurrence of sepsis, but the homozygosity of promoter $54(\mathrm{~A} / \mathrm{A})$ and promoter $-550(\mathrm{H} / \mathrm{H})$ is associated with the degree of severity of sepsis, but is not related to the outcome of sepsis. Mills et al. [48] genotyped and analyzed four MBL2 mononucleotide polymorphisms (rs5030737, rs1800450, rs1800451, rs7096206) in 1,839 European patients with community-acquired pneumonia and peritonitis sepsis and found that, in this large cohort of adult patients, there was no obvious association between the MBL2 gene polymorphism and the susceptibility to sepsis.

When the MBL gene polymorphism is inconsistent with the research results of sepsis susceptibility, a meta-analysis is the best analysis method. Compared with traditional descriptive literature reviews, a meta-analysis is a quantitative analysis method with better accuracy and higher testing power [49].

The current study summarized the research articles on the association between MBL gene polymorphism and sepsis published before December 1, 2019, then conducted a meta-analysis to analyze the association between the MBL gene polymorphism and the risk of sepsis. The results suggested that allele 0 may increase the risk of sepsis overall and that, among the three models of the MBL $+54 \mathrm{~A} / \mathrm{B}$ gene polymorphism, the MBL $+54 \mathrm{~A} / \mathrm{B}$ gene polymorphism had a significant correlation with the risk of sepsis. In the adult group, the $\mathrm{MBL} A / 0$ gene polymorphism was related to the risk of sepsis in the dominant and allele model, while the MBL+54A/B gene polymorphism was significantly related to the risk of sepsis in the recessive model. In the children group, none of the polymorphic sites were found to be significantly related to the occurrence of sepsis in any of the three models.

For data sets with $\geq 10$ articles, funnel plots, Begg's tests, and Egger's tests were used to evaluate the possibility of publication bias. For the total and adult groups, the results demonstrated no publication bias in the unadjusted estimate of the association between the MBL A/O and -211Y/X gene polymorphism and sepsis.

In summary, the $M B L$ gene polymorphisms that are closely related to the occurrence of sepsis are primarily $\mathrm{A} / \mathrm{O}$ and $+54 \mathrm{~A} / \mathrm{B}$, Although not every model or population has consistent results; $\mathrm{MBL}-221 \mathrm{Y} / \mathrm{X}$ and $-550 \mathrm{H} / \mathrm{L}$ have no obvious association with the occurrence of sepsis in different age groups or different models. 
There are still some limitations to the current study. First, the populations included in the study came from different countries/regions, hospitals, and/or treatment levels. In addition, there were disparities in the detection methods of the genotypes in the studies, the sources of specimens were also different, and the control group settings were inconsistent, all of which might affect the correlation between the genetic polymorphism and the risk of sepsis. Finally, the current study only collected the English documents from the three major databases; documents in other languages or other databases would inevitably be missed, which would affect the results.

Conclusions The polymorphisms of $\mathrm{MBL}$ that are related to the occurrence of sepsis are primarily $\mathrm{A} / \mathrm{O}$ and $+54 \mathrm{~A} / \mathrm{B}$, while $-221 \mathrm{Y} / \mathrm{X}$ and $-550 \mathrm{H} / \mathrm{L}$ have no clear relationship with the susceptibility of sepsis in various age groups or different models.

\section{Declarations}

\section{- Conflict of Interest}

The authors declare that the research was conducted in the absence of any commercial or financial relationships that could be construed as a potential conflict of interest.

- Ethics approval and consent to participate (Not applicable)

- Consent for publication(Not applicable)

- Availability of data and material(Not applicable)

- Competing interests(Not applicable)

- Funding

This study was supported by Hainan Provincial Natural Science Foundation of China [grant number 818MS140], National Natural Science Foundation of China [grant number 81860347], Military Medical Innovation Project [grant number 18CXZ002], Open Project of the State Key Laboratory of Trauma, Burn and Combined Injury, Third Military Medical University(NO. SKLKF202003).

\section{- Author contributions}

SC, JZ and XL are the guarantees of the integrity of the entire study and all authors (SC, JZ, XL, YW, JS, $\mathrm{XL}$ and $\mathrm{FG}$ ) contributed to the study concept and the design and definition of the intellectual content of this study. SC, JZ and XL contributed to finding papers and analysing statistics. SC, YW and JS contributed to the preparation of the manuscript. XL and FG contributed to the manuscript review. All authors read and approved the final manuscript.

\section{- Acknowledgements}

This study was supported by Hainan Provincial Natural Science Foundation of China (818MS140),National Natural Science Foundation of China (81860347),Military Medical Innovation 
Project (18CXZ002), Open Project of the State Key Laboratory of Trauma, Burn and Combined Injury, Third Military Medical University(NO. SKLKF202003).

\section{References}

1. Rochwerg B, Alhazzani W, Sindi A, Heels-Ansdell D, Thabane L, Fox-Robichaud A, et al; Fluids in Sepsis and Septic Shock Group. Fluid resuscitation in sepsis: a systematic review and network metaanalysis. Ann Intern Med. 2014 Sep 2;161(5):347-55. doi: 10.7326/M14-0178.

2. Deitch EA, Dayal SD. Intensive care unit management of the trauma patient. Crit Care Med. 2006 Sep;34(9):2294-301. doi: 10.1097/01.

3. Cooke GS, Hill AV. Genetics of susceptibility to human infectious disease. Nat Rev Genet. 2001 Dec;2(12):967-77. doi: 10.1038/35103577.

4. Risch NJ. Searching for genetic determinants in the new millennium. Nature. 2000 Jun 15;405(6788):847-56. doi: 10.1038/35015718.

5. Shi L, Takahashi K, Dundee J, Shahroor-Karni S, Thiel S, Jensenius JC, et al; Mannose-binding lectindeficient mice are susceptible to infection with Staphylococcus aureus. J Exp Med. 2004 May 17;199(10):1379-90. doi: 10.1084/jem.20032207.

6. Turner MW. The role of mannose-binding lectin in health and disease. Mol Immunol. 2003 Nov;40(7):423-9. doi: 10.1016/s0161-5890(03)00155-x.

7. Thiel S, Frederiksen PD, Jensenius JC. Clinical manifestations of mannan-binding lectin deficiency. Mol Immunol. 2006 Jan;43(1-2):86-96. doi: 10.1016/j.molimm.2005.06.018.

8. Gao DN, Zhang Y, Ren YB, Kang J, Jiang L, Feng Z, Qu YN, Qi QH, Meng X. Relationship of serum mannose-binding lectin levels with the development of sepsis: a meta-analysis. Inflammation. 2015 Feb;38(1):338-47. doi: 10.1007/s10753-014-0037-5.

9. Hartz A, Pagel J, Humberg A, Preuss M, Schreiter L, Rupp J, et al; German Neonatal Network (GNN). The association of mannose-binding lectin 2 polymorphisms with outcome in very low birth weight infants. PLoS One. 2017 May 30;12(5):e0178032. doi: 10.1371/journal.pone.0178032.

10. Garred P, J Strøm J, Quist L, Taaning E, Madsen HO. Association of mannose-binding lectin polymorphisms with sepsis and fatal outcome, in patients with systemic inflammatory response syndrome. J Infect Dis. 2003 Nov 1;188(9):1394-403. doi: 10.1086/379044.

11. Luo J, Xu F, Lu GJ, Lin HC, Feng ZC. Low mannose-binding lectin (MBL) levels and MBL genetic polymorphisms associated with the risk of neonatal sepsis: An updated meta-analysis. Early Hum Dev. 2014 Oct;90(10):557-64. doi: 10.1016/j.earlhumdev.2014.07.007.

12. Dzwonek AB, Neth OW, Thiébaut R, Gulczynska E, Chilton M, Hellwig T, et al. The role of mannosebinding lectin in susceptibility to infection in preterm neonates. Pediatr Res. 2008 Jun;63(6):680-5. doi: 10.1203/PDR.0b013e31816fdbff.

13. Xue H, Xue X, Yang C , Chen Q , Lin N, Lin Y, et al. Low Serum Mannose Binding Lectin (MBL) Levels and -221 YX Genotype of MBL2 Gene Are Susceptible to Neonatal Sepsis in the Chinese Han 
Population. Iranian Journal of Pediatrics. 2017, In Press(In Press). doi: 10.5812/ijp.9448

14. Świerzko AS, Szala-Poździej A, Kilpatrick DC, Sobociński M, Chojnacka K, Sokołowska A, et al. Components of the lectin pathway of complement activation in paediatric patients of intensive care units. Immunobiology. 2016 May;221(5):657-69. doi: 10.1016/j.imbio.2016.01.003. .

15. Liu L, Ning B. The role of MBL2 gene polymorphism in sepsis incidence. Int J Clin Exp Pathol. 2015 Nov 1;8(11):15123-7.

16. Mills TC, Chapman S, Hutton P, Gordon AC, Bion J, Chiche JD, et al. ESICM/ECCRN GenOSept Investigators. Variants in the Mannose-binding Lectin Gene MBL2 do not Associate With Sepsis Susceptibility or Survival in a Large European Cohort. Clin Infect Dis. 2015 Sep 1;61(5):695-703. doi: $10.1093 /$ cid/civ378.

17. Moreto A, Fariñas-Alvarez C, Puente M, Ocejo-Vinyals JG, Sánchez-Velasco P, Horcajada JP, et al. Mannose-binding lectin gene variants and infections in patients receiving autologous stem cell transplantation. BMC Immunol. 2014 May 3;15:17. doi: 10.1186/1471-2172-15-17.

18. Chong YP, Park KH, Kim ES, Kim MN, Kim SH, Lee SO, et al. Association of mannose-binding lectin 2 gene polymorphisms with persistent Staphylococcus aureus bacteremia. PLoS One. 2014 Mar 4;9(3):e89139. doi: 10.1371/journal.pone.0089139.

19. Bronkhorst MW, Lomax MA, Vossen RH, Bakker J, Patka P, van Lieshout EM. Risk of infection and sepsis in severely injured patients related to single nucleotide polymorphisms in the lectin pathway. Br J Surg. 2013 Dec;100(13):1818-26. doi: 10.1002/bjs.9319.

20. García-Laorden MI, Rodríguez de Castro F, Solé-Violán J, Payeras A, Briones ML, Borderías L, et al. The role of mannose-binding lectin in pneumococcal infection. Eur Respir J. 2013 Jan;41(1):131-9. doi: 10.1183/09031936.00174111.

21. Özkan H, Köksal N, Çetinkaya M, Kiliç Ş, Çelebi S, Oral B, et al. Serum mannose-binding lectin (MBL) gene polymorphism and low MBL levels are associated with neonatal sepsis and pneumonia. J Perinatol. 2012 Mar;32(3):210-7. doi: 10.1038/jp.2011.79.

22. de Rooij BJ, van Hoek B, ten Hove WR, Roos A, Bouwman LH, Schaapherder AF, et al. Lectin complement pathway gene profile of donor and recipient determine the risk of bacterial infections after orthotopic liver transplantation. Hepatology. 2010 Sep;52(3):1100-10. doi: 10.1002/hep.23782.

23. Klostergaard A, Steffensen R, Møller JK, Peterslund N, Juhl-Christensen C, Mølle I. Sepsis in acute myeloid leukaemia patients receiving high-dose chemotherapy: no impact of chitotriosidase and mannose-binding lectin polymorphisms. Eur J Haematol. 2010 Jul;85(1):58-64. doi: 10.1111/j.16000609.2010.01443.x.

24. Smithson A, Perello R, Aibar J, Espinosa G, Tassies D, Freire C, et al. Genotypes coding for low serum levels of mannose-binding lectin are underrepresented among individuals suffering from noninfectious systemic inflammatory response syndrome. Clin Vaccine Immunol. 2010 Mar;17(3):447-53. doi: 10.1128/CVI.00375-09.

25. Davis SM, Clark EA, Nelson LT, Silver RM. The association of innate immune response gene polymorphisms and puerperal group A streptococcal sepsis. Am J Obstet Gynecol. 2010 
Mar;202(3):308.e1-8. doi: 10.1016/j.ajog.2010.01.006.

26. Auriti C, Prencipe G, Inglese R, Azzari C, Ronchetti MP, Tozzi A, et al. Role of mannose-binding lectin in nosocomial sepsis in critically ill neonates. Hum Immunol. 2010 Nov;71(11):1084-8. doi: 10.1016/j.humimm.2010.08.012.

27. Koroglu OA, Onay H, Erdemir G, Yalaz M, Cakmak B, Akisu M, et al. Mannose-binding lectin gene polymorphism and early neonatal outcome in preterm infants. Neonatology. 2010;98(4):305-12. doi: $10.1159 / 000291487$.

28. Huh JW, Song K, Yum JS, Hong SB, Lim CM, Koh Y. Association of mannose-binding lectin-2 genotype and serum levels with prognosis of sepsis. Crit Care. 2009;13(6):R176. doi: $10.1186 / \mathrm{cc} 8157$.

29. Cervera C, Balderramo D, Suárez B, Prieto J, Fuster F, Linares L, et al. Donor mannose-binding lectin gene polymorphisms influence the outcome of liver transplantation. Liver Transpl. 2009 Oct;15(10):1217-24. doi: 10.1002/lt.21834.

30. Horcajada JP, Lozano F, Muñoz A, Suarez B, Fariñas-Alvarez C, Almela M, et al. Polymorphic receptors of the innate immune system (MBL/MASP-2 and TLR2/4) and susceptibility to pneumococcal bacteremia in HIV-infected patients: a case-control study. Curr HIV Res. 2009 Mar;7(2):218-23. doi: 10.2174/157016209787581382.

31. van der Zwet WC, Catsburg A, van Elburg RM, Savelkoul PH, Vandenbroucke-Grauls CM. Mannosebinding lectin $(\mathrm{MBL})$ genotype in relation to risk of nosocomial infection in pre-term neonates in the neonatal intensive care unit. Clin Microbiol Infect. 2008 Feb;14(2):130-5. doi: 10.1111/j.14690691.2007.01886.x.

32. Dzwonek AB, Neth OW, Thiébaut R, Gulczynska E, Chilton M, Hellwig T, et al. The role of mannosebinding lectin in susceptibility to infection in preterm neonates. Pediatr Res. 2008 Jun;63(6):680-5. doi: 10.1203/PDR.0b013e31816fdbff.

33. Huttunen R, Aittoniemi J, Laine J, Vuento R, Karjalainen J, Rovio AT, et al. Gene-environment interaction between MBL2 genotype and smoking, and the risk of gram-positive bacteraemia. Scand J Immunol. 2008 Oct;68(4):438-44. doi: 10.1111/j.1365-3083.2008.02149.x.

34. Hellemann D, Larsson A, Madsen HO, Bonde J, Jarløv JO, Wiis J, et al. Heterozygosity of mannosebinding lectin (MBL2) genotypes predicts advantage (heterosis) in relation to fatal outcome in intensive care patients. Hum Mol Genet. 2007 Dec 15;16(24):3071-80. doi: 10.1093/hmg/ddm265.

35. Frakking FN, Brouwer N, van Eijkelenburg NK, Merkus MP, Kuijpers TW, Offringa M, et al. Low mannose-binding lectin (MBL) levels in neonates with pneumonia and sepsis. Clin Exp Immunol. 2007 Nov;150(2):255-62. doi: 10.1111/j.1365-2249.2007.03479.x.

36. Eisen DP, Dean MM, Thomas P, Marshall P, Gerns N, Heatley S, et al. Low mannose-binding lectin function is associated with sepsis in adult patients. FEMS Immunol Med Microbiol. 2006 Nov;48(2):274-82. doi: 10.1111/j.1574-695X.2006.00144.x.

37. Gordon AC, Waheed U, Hansen TK, Hitman GA, Garrard CS, Turner MW, et al. Mannose-binding lectin polymorphisms in severe sepsis: relationship to levels, incidence, and outcome. Shock. 2006 
Jan;25(1):88-93. doi: 10.1097/01.shk.0000186928.57109.8d.

38. Mølle I, Peterslund NA, Thiel S, Steffensen R. MBL2 polymorphism and risk of severe infections in multiple myeloma patients receiving high-dose melphalan and autologous stem cell transplantation. Bone Marrow Transplant. 2006 Oct;38(8):555-60. doi: 10.1038/sj.bmt.1705466.

39. Horiuchi T, Gondo H, Miyagawa H, Otsuka J, Inaba S, Nagafuji K, et al. Association of MBL gene polymorphisms with major bacterial infection in patients treated with high-dose chemotherapy and autologous PBSCT. Genes Immun. 2005 Mar;6(2):162-6. doi: 10.1038/sj.gene.6364165.

40. Fidler KJ, Wilson P, Davies JC, Turner MW, Peters MJ, Klein NJ. Increased incidence and severity of the systemic inflammatory response syndrome in patients deficient in mannose-binding lectin. Intensive Care Med. 2004 Jul;30(7):1438-45. doi: 10.1007/s00134-004-2303-8.

41. Ahrens P, Kattner E, Köhler B, Härtel C, Seidenberg J, Segerer H, et al. Genetic Factors in Neonatology Study Group. Mutations of genes involved in the innate immune system as predictors of sepsis in very low birth weight infants. Pediatr Res. 2004 Apr;55(4):652-6. doi:

10.1203/01.PDR.0000112100.61253.85.

42. Garred P, J Strøm J, Quist L, Taaning E, Madsen HO. Association of mannose-binding lectin polymorphisms with sepsis and fatal outcome, in patients with systemic inflammatory response syndrome. J Infect Dis. 2003 Nov 1;188(9):1394-403. doi: 10.1086/379044.

43. Kronborg G, Weis N, Madsen HO, Pedersen SS, Wejse C, Nielsen H, et al. Variant mannose-binding lectin alleles are not associated with susceptibility to or outcome of invasive pneumococcal infection in randomly included patients. J Infect Dis. 2002 May 15;185(10):1517-20. doi: 10.1086/340216.

44. Madsen HO, Garred P, Kurtzhals JA, Lamm LU, Ryder LP, Thiel S, et al. A new frequent allele is the missing link in the structural polymorphism of the human mannan-binding protein. Immunogenetics. 1994;40(1):37-44. doi: 10.1007/BF00163962.

45. Liu L, Ning B. The role of MBL2 gene polymorphism in sepsis incidence. Int J Clin Exp Pathol. 2015 Nov 1;8(11):15123-7.

46. Özkan H, Köksal N, Çetinkaya M, Kiliç Ş, Çelebi S, Oral B, et al. Serum mannose-binding lectin (MBL) gene polymorphism and low MBL levels are associated with neonatal sepsis and pneumonia. $J$ Perinatol. 2012 Mar;32(3):210-7. doi: 10.1038/jp.2011.79.

47. Huh JW, Song K, Yum JS, Hong SB, Lim CM, Koh Y. Association of mannose-binding lectin-2 genotype and serum levels with prognosis of sepsis. Crit Care. 2009;13(6):R176. doi: $10.1186 /$ cc8157.

48. Mills TC, Chapman S, Hutton P, Gordon AC, Bion J, Chiche JD, et al; ESICM/ECCRN GenOSept Investigators. Variants in the Mannose-binding Lectin Gene MBL2 do not Associate With Sepsis Susceptibility or Survival in a Large European Cohort. Clin Infect Dis. 2015 Sep 1;61(5):695-703. doi: 10.1093/cid/civ378.

49. Stroup DF, Berlin JA, Morton SC, Olkin I, Williamson GD, Rennie D, et al. Meta-analysis of observational studies in epidemiology: a proposal for reporting. Meta-analysis Of Observational 
Studies in Epidemiology (MOOSE) group. JAMA. 2000 Apr 19;283(15):2008-12. doi: 10.1001/jama.283.15.2008.

\section{Tables}




\begin{tabular}{|c|c|c|c|c|}
\hline Author/publication year/reference & Group & Case & Control & Polymorphism \\
\hline Hartz.A.2017[9] & Paediatric & 2765 & 4113 & $\mathrm{~A} / \mathrm{O}$ \\
\hline Xue. H.2017[13] & Paediatric & 48 & 96 & $-221 \mathrm{YX}, \mathrm{P} / \mathrm{Q}$ \\
\hline Świerzko. A.S.2016(1)[14] & Paediatric & 87 & 313 & $\mathrm{~A} / \mathrm{O}$ \\
\hline Świerzko.A.S.2016(2)[14] & Paediatric & 87 & 47 & $\mathrm{~A} / \mathrm{O}$ \\
\hline Liu.L.2015[15] & Adult & 107 & 134 & $+54 \mathrm{~A} / \mathrm{B}$ \\
\hline Mills.T.C.2015[16] & Adult & 496 & 477 & $\mathrm{~A} / 0,-221 \mathrm{Y} / \mathrm{X}$ \\
\hline Moreto.A.2014 [17] & Adult & 31 & 41 & $\mathrm{~A} / \mathrm{O}$ \\
\hline Chong.Y.P.2014 [18] & Adult & 41 & 46 & $\begin{array}{l}+54 \mathrm{~A} / \mathrm{B},-221 \mathrm{Y} / \mathrm{X} \\
-550 \mathrm{HL}\end{array}$ \\
\hline Bronkhorst.M.W.2013[19] & Adult & 116 & 103 & $\mathrm{~A} / 0,-221 \mathrm{Y} / \mathrm{X}$ \\
\hline Garcia-Laorden.M.I.2013[20] & Adult & 152 & 196 & $\mathrm{~A} / 0,-221 \mathrm{Y} / \mathrm{X}$ \\
\hline Ozkan.H.2012[21] & Paediatric & 53 & 40 & $+54 \mathrm{~A} / \mathrm{B}$ \\
\hline deRooij.B.J.F.2010[22] & Adult & 59 & 84 & $\mathrm{~A} / 0,-221 \mathrm{Y} / \mathrm{X}$ \\
\hline Klostergaard.A.2010[23] & Adult & 143 & 47 & $\mathrm{~A} / 0,-221 \mathrm{Y} / \mathrm{X}$ \\
\hline Smithson.A.2010[24] & Adult & 164 & 52 & $\mathrm{~A} / 0,-221 \mathrm{Y} / \mathrm{X}$ \\
\hline Davis.S.M.2010[25] & Adult & 28 & 53 & $\begin{array}{l}+54 \mathrm{~A} / \mathrm{B},-221 \mathrm{Y} / \mathrm{X} \\
-550 \mathrm{HL}\end{array}$ \\
\hline Auriti.C.2010[26] & Paediatric & 42 & 85 & $\mathrm{~A} / 0,-221 \mathrm{Y} / \mathrm{X}$ \\
\hline Koroglu.O.A.2010[27] & Paediatric & 42 & 60 & $+54 \mathrm{~A} / \mathrm{B}$ \\
\hline Huh.J.W.2009[28] & Adult & 266 & 396 & $+54 \mathrm{~A} / \mathrm{B},-550 \mathrm{HL}$ \\
\hline Cervera.C.2009[29] & Adult & 39 & 28 & $\mathrm{~A} / \mathrm{O}$ \\
\hline Horcajada.J.P.2009[30] & Adult & 57 & 114 & $\mathrm{~A} / 0,-221 \mathrm{Y} / \mathrm{X}$ \\
\hline van der Zwet.W.C.2008[31] & Paediatric & 41 & 145 & $A / 0,-221 Y / X$ \\
\hline Dzwonek.A.B.2008[32] & Paediatric & 38 & 82 & $\mathrm{~A} / \mathrm{O}$ \\
\hline Huttunen.R.2008[33] & Adult & 145 & 400 & $\mathrm{~A} / 0,-221 \mathrm{Y} / \mathrm{X}$ \\
\hline Hellemann.D.2007[34] & Adult & 376 & 689 & $\mathrm{~A} / 0,-221 \mathrm{Y} / \mathrm{X}$ \\
\hline Frakking.F.N.J.2007[35] & Paediatric & 10 & 38 & $\mathrm{~A} / \mathrm{O}$ \\
\hline Eisen.D.P.2006[36] & Adult & 170 & 236 & $\begin{array}{l}\text { A/O, }-221 Y / X \\
-550 \mathrm{H} / \mathrm{L}\end{array}$ \\
\hline
\end{tabular}




\begin{tabular}{|lllll|}
\hline Gordon.A.C.2006[37] & Adult & 174 & 353 & $\mathrm{~A} / \mathrm{O}$ \\
\hline Molle.I.2006[38] & Adult & 11 & 102 & $\mathrm{~A} / \mathrm{O}$ \\
\hline Horiuchi.T.2005[39] & Adult & 7 & 106 & $+54 \mathrm{~A} / \mathrm{B}$ \\
\hline Fidler.K.J. 2004[40] & Paediatric & 35 & 15 & $\mathrm{~A} / 0$ \\
\hline Ahrens.P.2004[41] & Paediatric & 50 & 306 & $\mathrm{~A} / 0$ \\
\hline Garred.P.2003[42] & Adult & 197 & 75 & $\mathrm{~A} / 0,-221 \mathrm{Y} / \mathrm{X}$ \\
\hline Kronborg.G.2002[43] & Adult & 140 & 250 & $\mathrm{~A} / 0,-221 \mathrm{Y} / \mathrm{X}$ \\
\hline
\end{tabular}

Table 1. Characteristics of studies included in the meta-analysis. 


\begin{tabular}{|c|c|c|c|c|c|c|c|}
\hline \multirow[t]{2}{*}{ Groups } & \multirow[t]{2}{*}{ Model } & \multicolumn{2}{|l|}{ Cases } & \multirow{2}{*}{$\begin{array}{l}\text { Odds Ratio (95\% } \\
\mathrm{Cl})\end{array}$} & \multirow[t]{2}{*}{$P$ value } & \multicolumn{2}{|c|}{ Heterogeneity } \\
\hline & & Sepsis & Control & & & $P$ value & $\mathrm{I}^{2}$ \\
\hline \multicolumn{8}{|l|}{ Total } \\
\hline \multirow[t]{3}{*}{$\mathrm{A} / \mathrm{O}$} & $\begin{array}{l}00+A 0 \text { vs. } \\
\text { AA }\end{array}$ & 5585 & 8431 & $1.23[0.97,1.55]$ & 0.08 & $<0.00001$ & $84 \%$ \\
\hline & $\begin{array}{l}O O \text { vs. } \\
A O+A A\end{array}$ & 5312 & 7735 & $1.29[0.96,1.75]$ & 0.09 & 0.03 & $43 \%$ \\
\hline & O vs. A & 10624 & 15470 & $1.14[1.00,1.29]$ & 0.04 & 0.002 & $57 \%$ \\
\hline \multirow[t]{3}{*}{$-211 Y / X$} & $\begin{array}{l}X X+Y X \text { vs. } \\
Y Y\end{array}$ & 2315 & 3018 & $1.02[0.90,1.14]$ & 0.79 & 0.75 & $0 \%$ \\
\hline & $\begin{array}{l}X X v s . \\
Y X+Y Y\end{array}$ & 2315 & 3018 & $0.96[0.73,1.27]$ & 0.80 & 0.09 & $36 \%$ \\
\hline & X vs. Y & 4630 & 6036 & $1.01[0.91,1.11]$ & 0.89 & 0.93 & $0 \%$ \\
\hline \multirow[t]{3}{*}{$-550 \mathrm{H} / \mathrm{L}$} & $\begin{array}{l}\mathrm{LL}+\mathrm{HL} \text { vs. } \\
\mathrm{HH}\end{array}$ & 449 & 687 & $0.91[0.69,1.21]$ & 0.53 & 0.34 & $8 \%$ \\
\hline & $\begin{array}{l}\text { LL vs. } \\
\mathrm{HL}+\mathrm{HH}\end{array}$ & 449 & 687 & $0.98[0.75,1.29]$ & 0.91 & 0.79 & $0 \%$ \\
\hline & Lvs. H & 898 & 1374 & $0.96[0.81,1.14]$ & 0.65 & 0.58 & $0 \%$ \\
\hline \multirow[t]{3}{*}{$+54 \mathrm{~A} / \mathrm{B}$} & $\begin{array}{l}\mathrm{BB}+\mathrm{AB} \text { vs. } \\
\mathrm{AA}\end{array}$ & 533 & 832 & $2.01[1.08,3.75]$ & 0.03 & 0.0001 & $78 \%$ \\
\hline & $\begin{array}{l}\text { BB vs. } \\
A B+A A\end{array}$ & 438 & 732 & $6.32[3.89,10.27]$ & $<0.00001$ & 0.63 & $0 \%$ \\
\hline & B vs. A & 982 & 1544 & $2.09[1.03,4.24]$ & 0.04 & $<0.00001$ & $86 \%$ \\
\hline \multicolumn{8}{|l|}{ Adult } \\
\hline \multirow[t]{3}{*}{$\mathrm{A} / \mathrm{O}$} & $\begin{array}{l}O O+A O \text { vs. } \\
\text { AA }\end{array}$ & 2470 & 3247 & $1.37[1.10,1.72]$ & 0.006 & $<0.0001$ & $69 \%$ \\
\hline & $\begin{array}{l}O O \text { vs. } \\
A O+A A\end{array}$ & 2330 & 2992 & $1.24[0.96,1.59]$ & 0.10 & 0.33 & $12 \%$ \\
\hline & O vs. A & 4660 & 5984 & $1.19[1.00,1.41]$ & 0.04 & 0.002 & $63 \%$ \\
\hline \multirow[t]{3}{*}{$-211 Y / X$} & $\begin{array}{l}X X+Y X \text { vs. } \\
Y Y\end{array}$ & 2184 & 2692 & $0.99[0.88,1.12]$ & 0.87 & 0.96 & $0 \%$ \\
\hline & $\begin{array}{l}X X \text { vs. } \\
Y X+Y Y\end{array}$ & 2184 & 2692 & $1.05[0.79,1.41]$ & 0.73 & 0.09 & $38 \%$ \\
\hline & X vs. Y & 4368 & 5384 & $1.00[0.90,1.11]$ & 1.00 & 0.88 & $0 \%$ \\
\hline$+54 \mathrm{~A} / \mathrm{B}$ & $\begin{array}{l}\text { BB+AB vs. } \\
\text { AA }\end{array}$ & 438 & 732 & $1.74[0.82,3.67]$ & 0.15 & 0.0003 & $81 \%$ \\
\hline
\end{tabular}




\begin{tabular}{|c|c|c|c|c|c|c|c|}
\hline & $\begin{array}{l}\text { BB vs. } \\
A B+A A\end{array}$ & 438 & 732 & $6.32[3.89,10.27]$ & $<0.00001$ & 0.63 & $0 \%$ \\
\hline & B vs. A & 876 & 1464 & $1.82[0.87,3.79]$ & 0.11 & $<0.0001$ & $86 \%$ \\
\hline \multicolumn{8}{|c|}{ Paediatric } \\
\hline \multirow[t]{3}{*}{$\mathrm{A} / \mathrm{O}$} & $\begin{array}{l}O O+A O \text { vs. } \\
A A\end{array}$ & 3115 & 5184 & $0.99[0.90,1.08]$ & 0.78 & 0.001 & $69 \%$ \\
\hline & $\begin{array}{l}00 \text { vs. } \\
A O+A A\end{array}$ & 2982 & 4743 & $1.00[0.76,1.31]$ & 0.97 & 0.79 & $0 \%$ \\
\hline & O vs. A & 5964 & 9486 & $0.99[0.91,1.07]$ & 0.75 & 0.50 & $0 \%$ \\
\hline \multirow[t]{3}{*}{$-211 Y / X$} & $\begin{array}{l}X X+Y X \text { vs. } \\
Y Y\end{array}$ & 131 & 326 & $1.40[0.92,2.31]$ & 0.12 & 0.16 & $45 \%$ \\
\hline & $\begin{array}{l}X X \text { vs. } \\
Y X+Y Y\end{array}$ & 131 & 326 & $0.28[0.08,1.07]$ & 0.06 & 0.71 & $0 \%$ \\
\hline & X vs. Y & 262 & 652 & $1.10[0.77,1.58]$ & 0.60 & 0.59 & $0 \%$ \\
\hline
\end{tabular}

Table 2. The results of meta-analysis

\section{Figures}

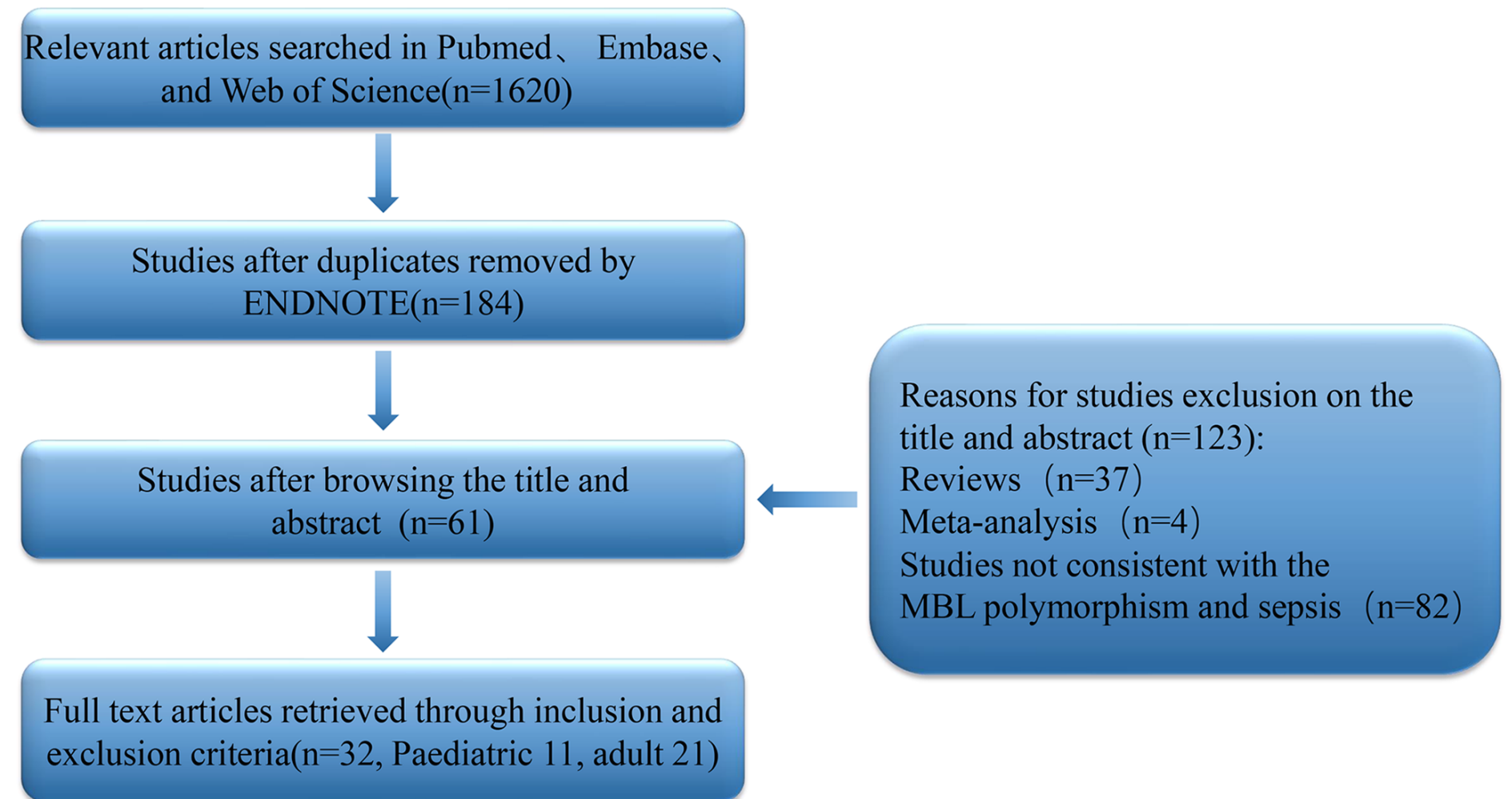

Figure 1 
Flow chart of literature search and selection process.

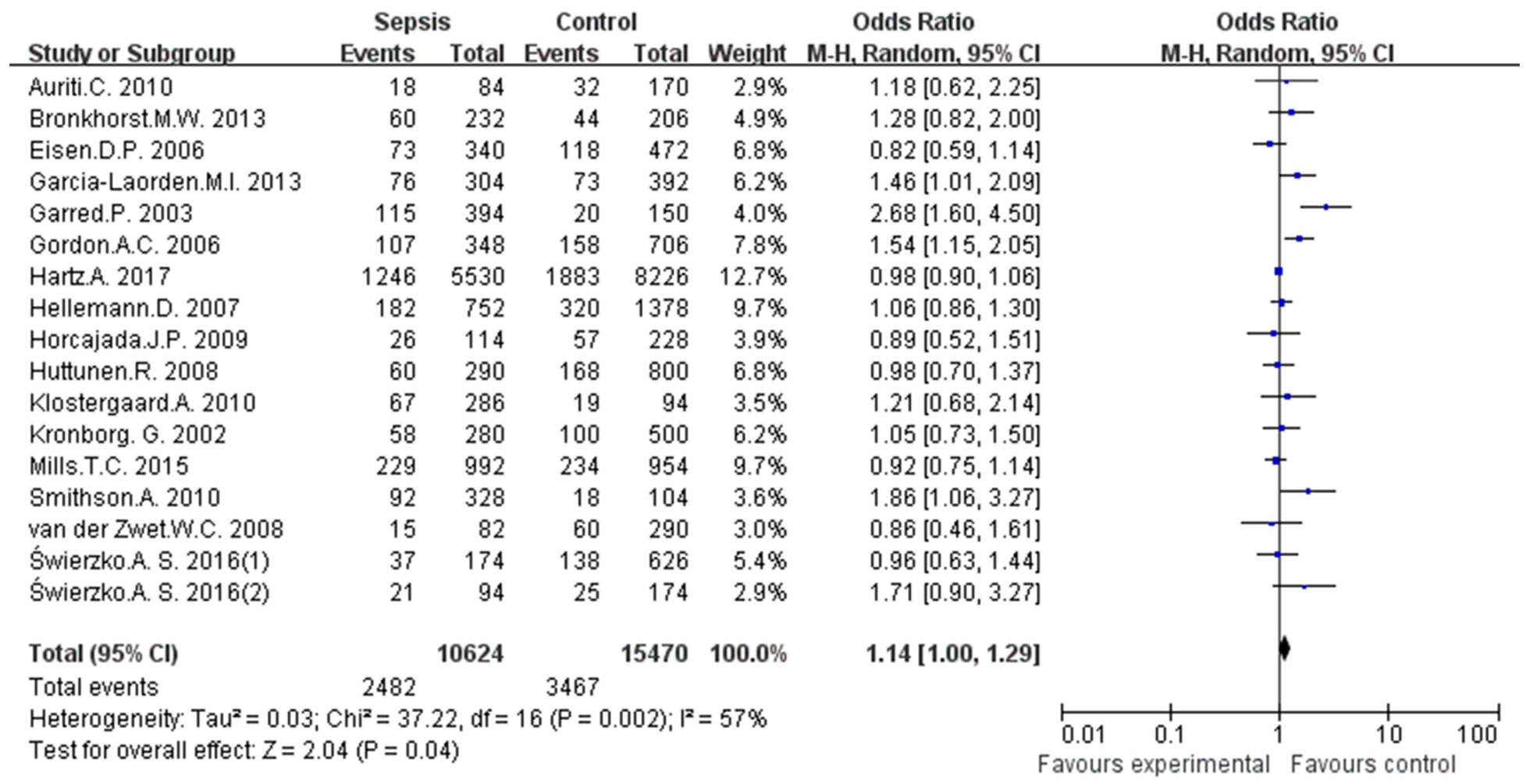

Figure 2

Analysis of $\mathrm{MBL} A / 0$ gene polymorphism and sepsis susceptibility in the allele model $O \mathrm{vs.} A$. 


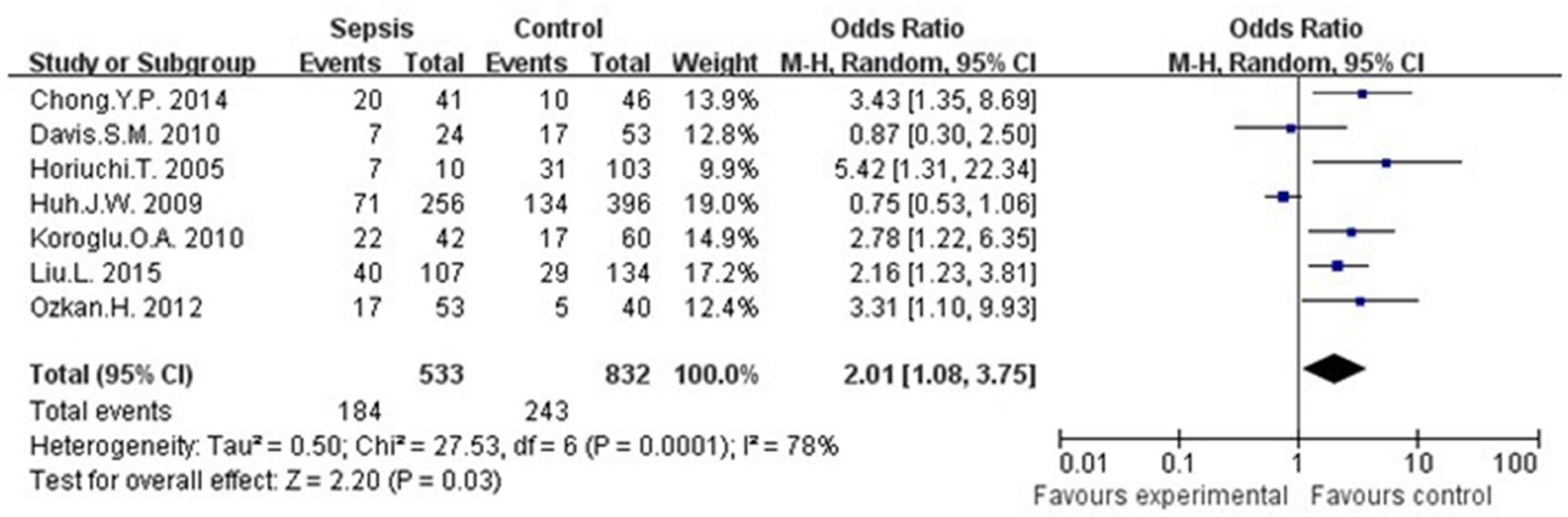

\section{$B B+A B$ VS. $A A$}

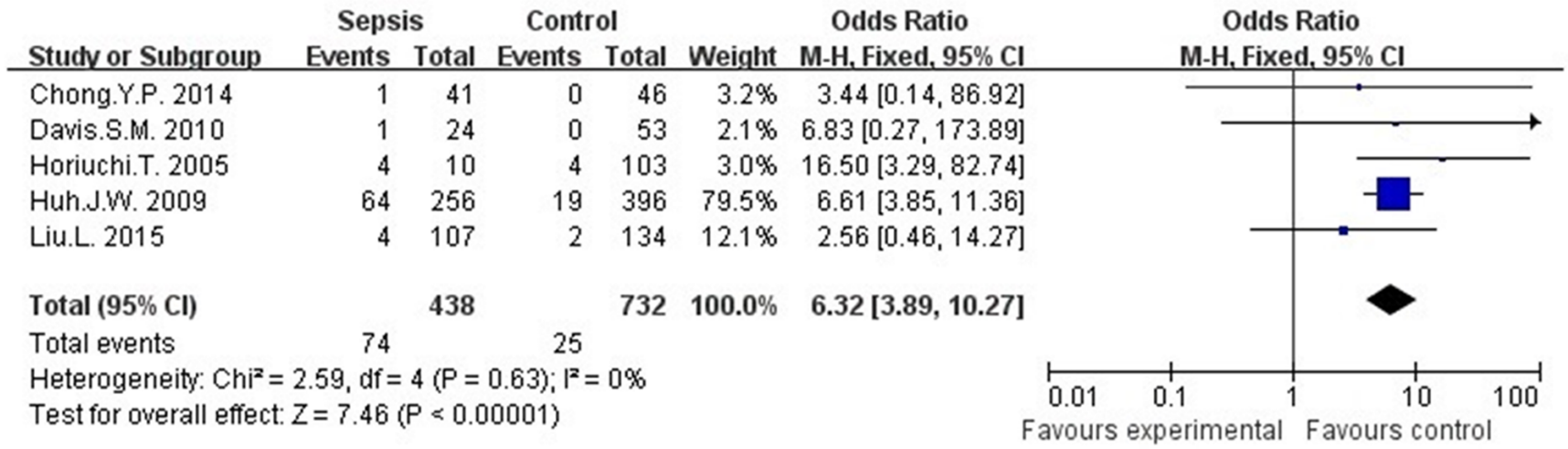

\section{$B B$ vs. $A B+A A$}

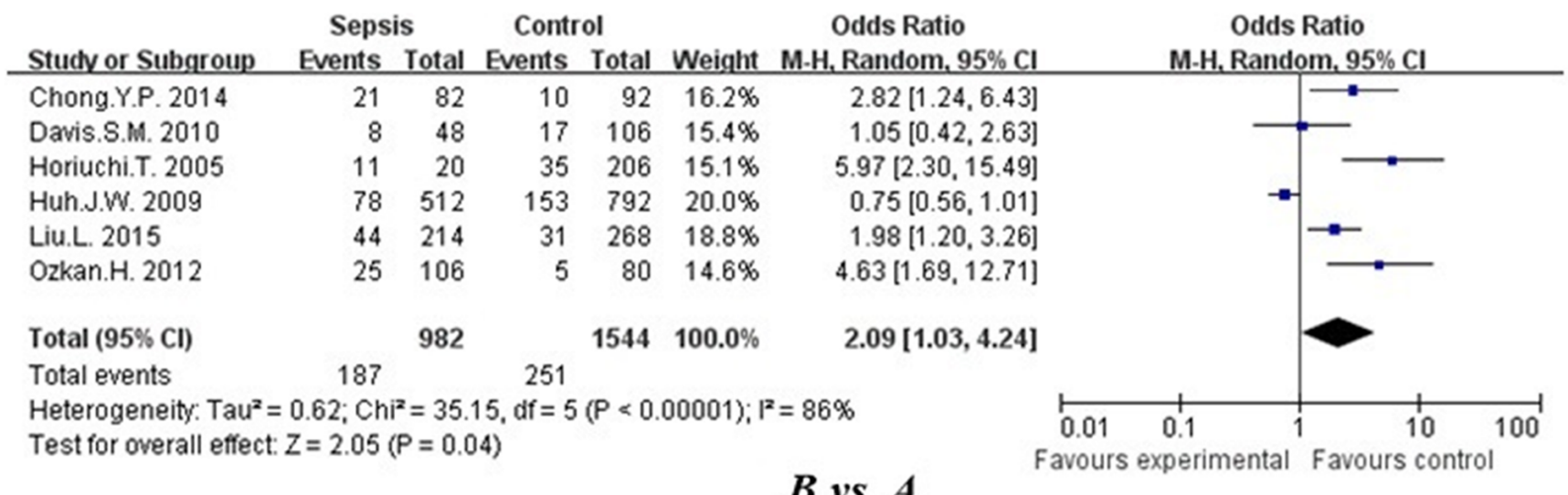

\section{Figure 3}

Analysis of MBL $+54 \mathrm{~A} / \mathrm{B}$ gene polymorphism and sepsis susceptibility in dominant model, recessive model and allelic model. 


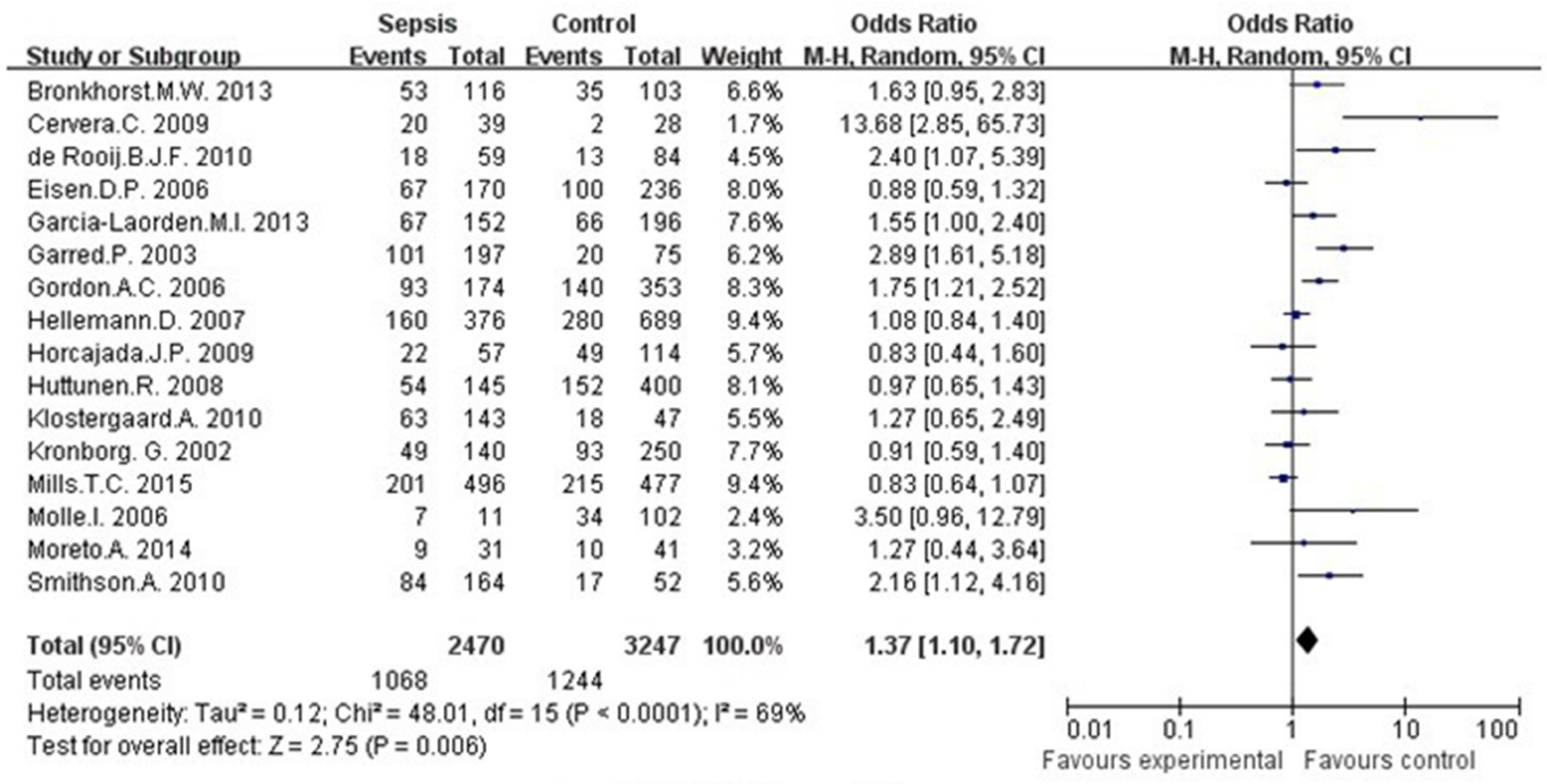

\section{$O O+A O$ vs. $A A$}

Sepsis Control Odds Ratio Odds Ratio

Study or Subgroup Events Total Events Total Weight M-H, Random, $95 \% \mathrm{Cl}$

\begin{tabular}{lrrrrr} 
Bronkhorst.M.W. 2013 & 60 & 232 & 44 & 206 & $7.2 \%$ \\
Eisen.D.P. 2006 & 73 & 340 & 118 & 472 & $9.3 \%$ \\
Garcia-Laorden.M.I. 2013 & 76 & 304 & 73 & 392 & $8.7 \%$ \\
Garred.P. 2003 & 115 & 394 & 20 & 150 & $6.1 \%$ \\
Gordon.A.C. 2006 & 107 & 348 & 158 & 706 & $10.2 \%$ \\
Hellemann.D. 2007 & 182 & 752 & 320 & 1378 & $11.9 \%$ \\
Horcajada.J.P. 2009 & 26 & 114 & 57 & 228 & $5.9 \%$ \\
Huttunen.R. 2008 & 60 & 290 & 168 & 800 & $9.3 \%$ \\
Klostergaard.A. 2010 & 67 & 286 & 19 & 94 & $5.4 \%$ \\
Kronborg. G. 2002 & 58 & 280 & 100 & 500 & $8.7 \%$ \\
Mills.T.C. 2015 & 229 & 992 & 234 & 954 & $11.9 \%$ \\
Smithson.A. 2010 & 92 & 328 & 18 & 104 & $5.5 \%$ \\
& & & & & \\
Total (95\% Cl) & & 4660 & & 5984 & $100.0 \%$ \\
Total events & 1145 & \multicolumn{5}{c}{1329} & &
\end{tabular}

Heterogeneity. Tau $^{2}=0.05 ; \mathrm{Chi}^{2}=29.62, \mathrm{df}=11(\mathrm{P}=0.002) ; \mathrm{I}^{2}=63 \%$

Test for overall effect: $Z=2.01(P=0.04)$

$O$ vs. $A$
$1.28[0.82,2.00]$

$0.82[0.59,1.14]$

$1.46[1.01,2.09]$

$2.68[1.60,4.50]$

$1.54[1.15,2.05]$

$1.06[0.86,1.30]$

$0.89[0.52,1.51]$

$0.98[0.70,1.37]$

$1.21[0.68,2.14]$

$1.05[0.73,1.50]$

$0.92[0.75,1.14]$

$1.86[1.06,3.27]$

$1.19[1.00,1.41]$

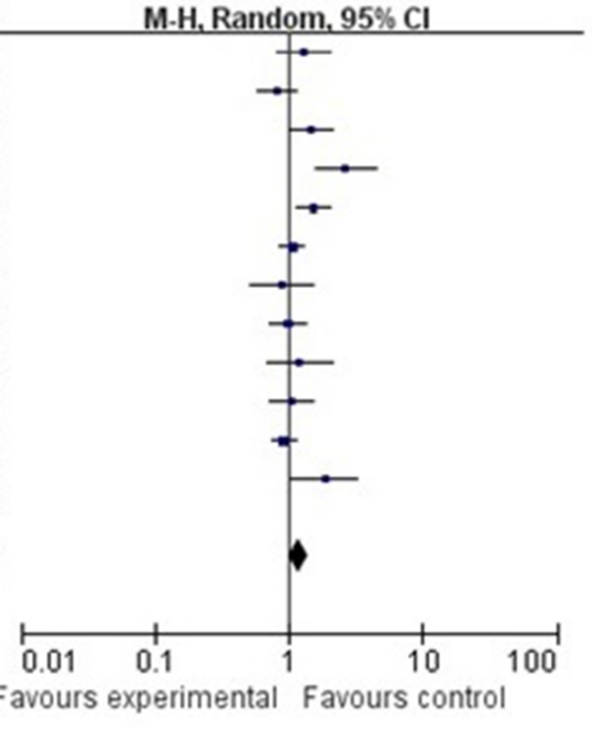

\section{Figure 4}

The analysis of $\mathrm{MBL} A / 0$ gene polymorphism and sepsis susceptibility in adult dominant and allelic models. 
Sepsis

Control

Odds Ratio

Odds Ratio

Studv or Subgroup Events Total Events Total Weight M-H, Fixed, 95\% Cl

Chong.Y.P. 2014

Davis.S.M. 2010

Horiuchi.T. 2005

Huh.J.W. 2009

Liu.L. 2015

$\begin{array}{rrrrrr}1 & 41 & 0 & 46 & 3.2 \% & 3.44[0.14,86.92] \\ 1 & 24 & 0 & 53 & 2.1 \% & 6.83[0.27,173.89] \\ 4 & 10 & 4 & 103 & 3.0 \% & 16.50[3.29,82.74] \\ 64 & 256 & 19 & 396 & 79.5 \% & 6.61[3.85,11.36] \\ 4 & 107 & 2 & 134 & 12.1 \% & 2.56[0.46,14.27]\end{array}$

Total (95\% Cl)

Total events

438

$732 \quad 100.0 \%$

$6.32[3.89,10.27]$

Heterogeneity: $\mathrm{Chi}^{2}=2.59, \mathrm{df}=4(\mathrm{P}=0.63) ; \mathrm{I}^{2}=0 \%$

Test for overall effect: $Z=7.46(P<0.00001)$

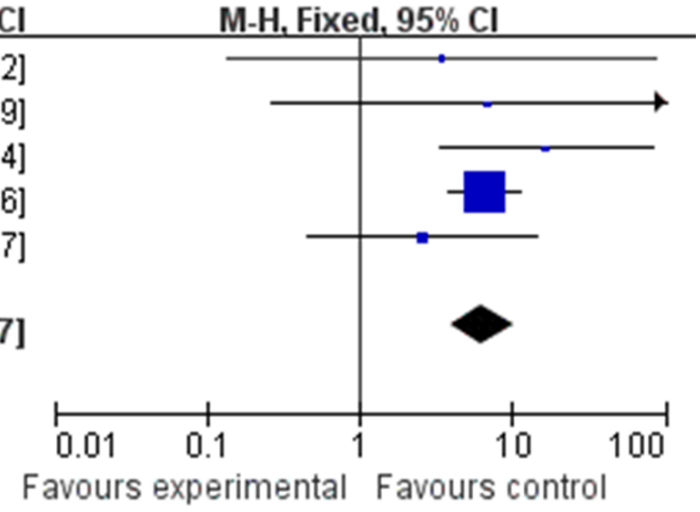

Figure 5

The analysis of $\mathrm{MBL}+54 \mathrm{~A} / \mathrm{B}$ gene polymorphism and sepsis susceptibility in adult recessive models.

Begg's funnel plot with pseudo 95\% confidence limits

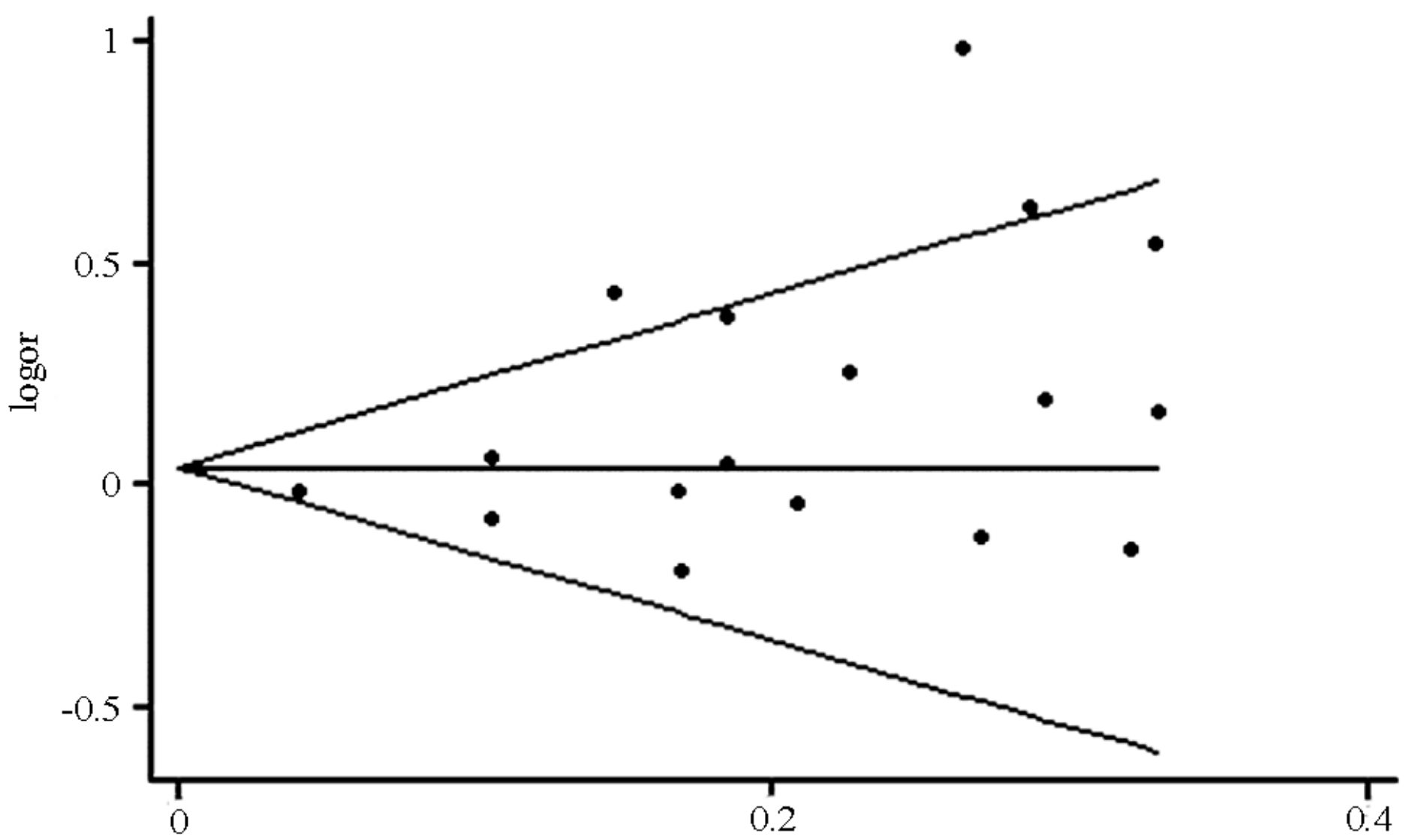

s. e. of: logor

Figure 6

The Begg funnel chart of the allelic model $O$ vs. A in total. 
Begg's funnel plot with pseudo 95\% confidence limits

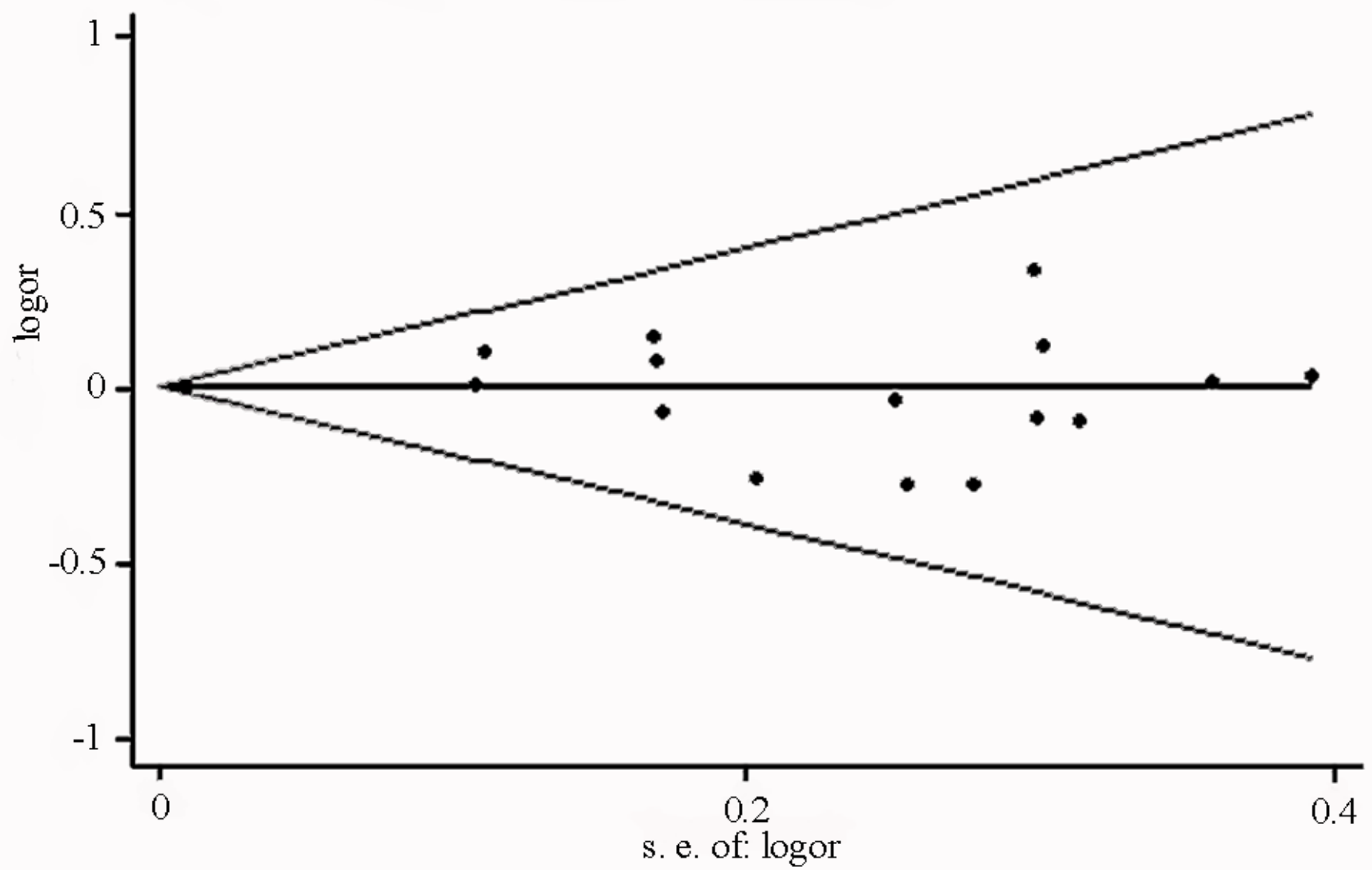

Figure 7

The Begg funnel chart of the allelic model $X$ vs. $Y$ in total. 
Begg's funnel plot with pseudo 95\% confidence limits

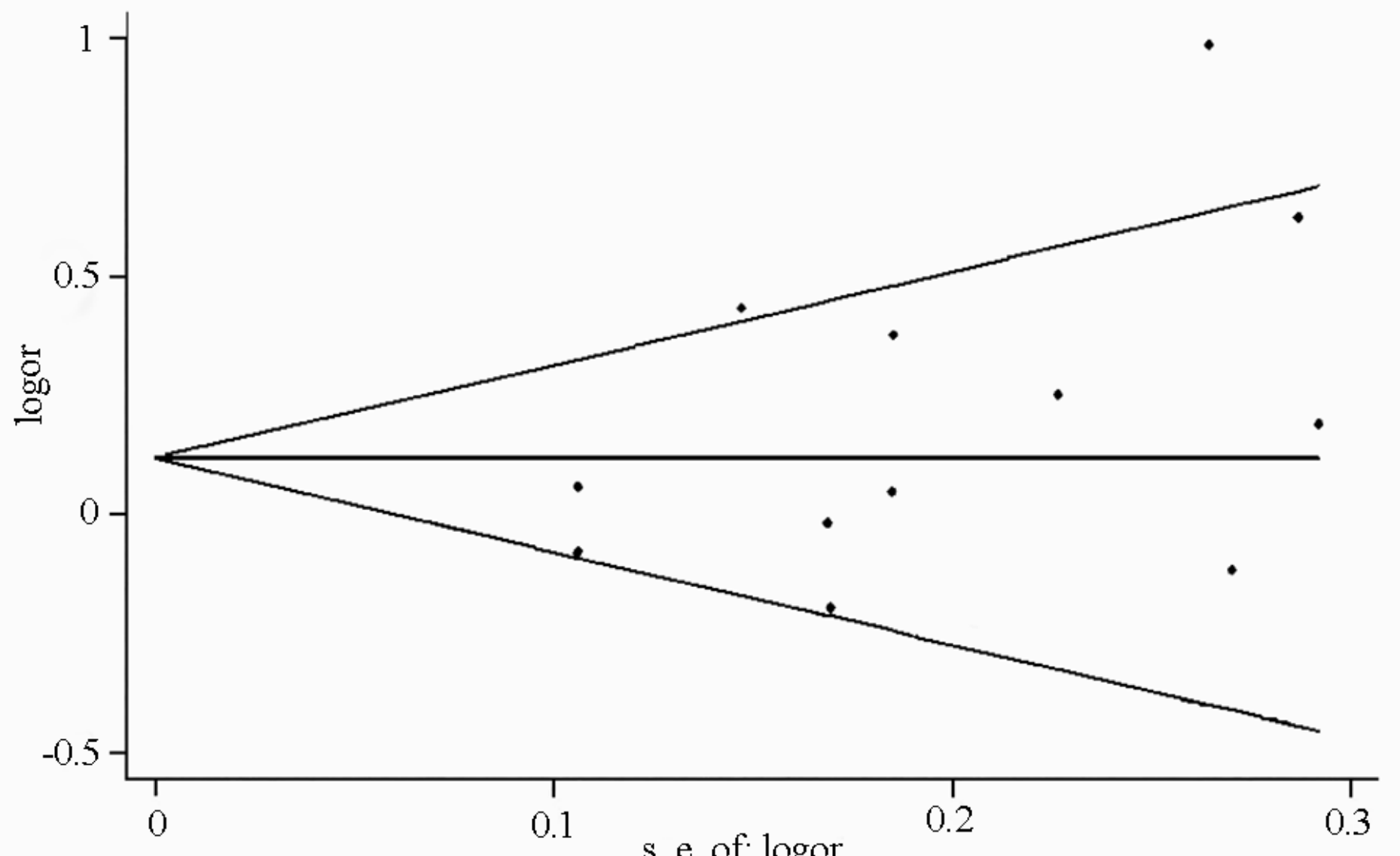

s. e. of: logor

Figure 8

The Begg funnel chart of the allelic model $\mathrm{O}$ vs. $\mathrm{A}$ in adult. 


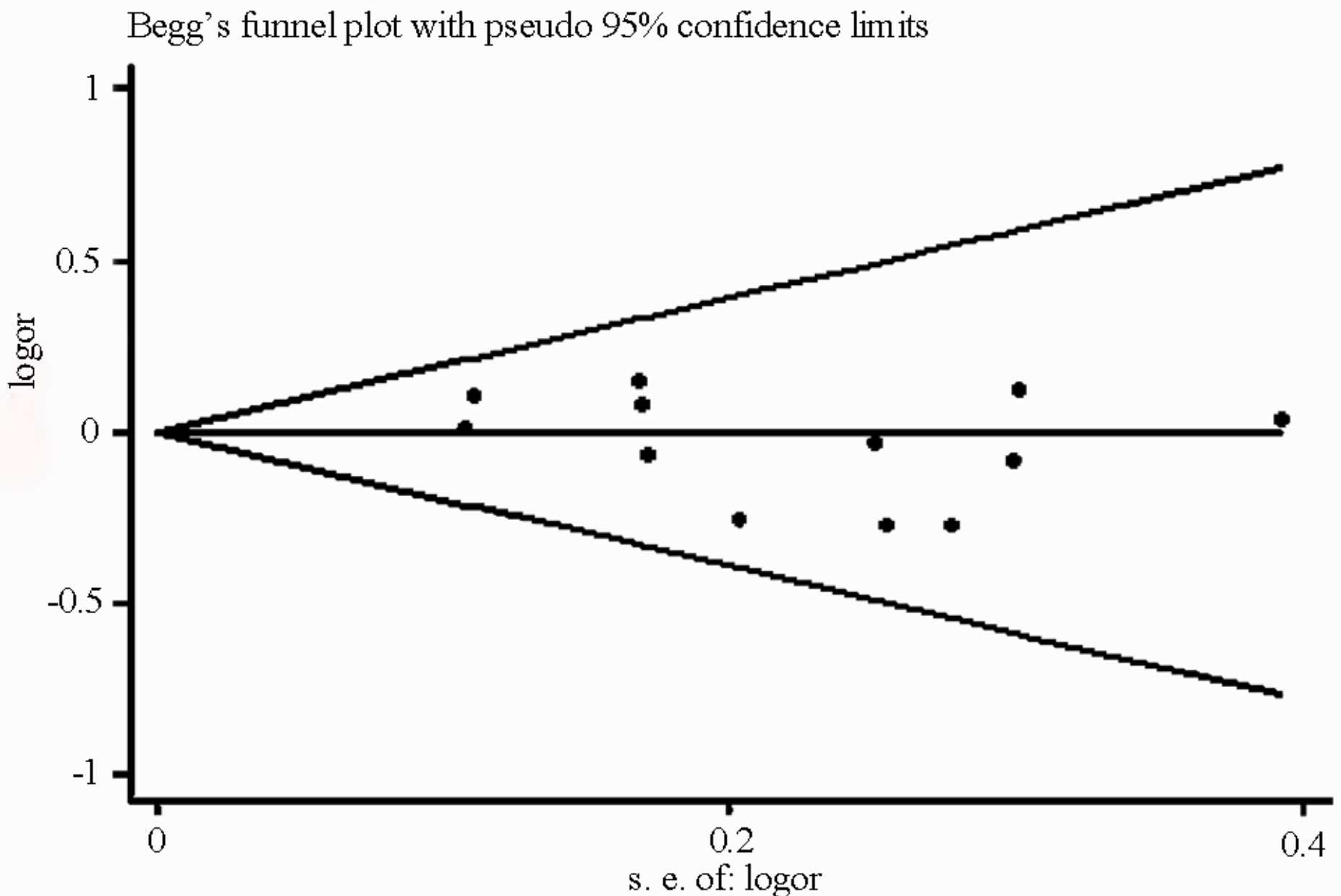

Figure 9

The Begg funnel chart of the allelic model $X$ vs. $Y$ in adult. 